\title{
埋立地に建設された人工海浜の維持管理 一侵食問題についてー
}

\section{BEACH EROSION OF AN ARTIFICIAL BEACH CONSTRUCTED IN THE RECLAIMED LAND}

\author{
矢内 栄二 ${ }^{1} \cdot$ 米田 規幸 $^{2} \cdot$ 六崎 信夫 $^{3}$ \\ Eiji YAUCHI ${ }^{1}$, Noriyuki YONEDA ${ }^{2}$, Nobuo MUTUZAKI ${ }^{3}$ \\ 1正会員 工博 千葉工業大学 工学部土木工学科（广275-8588 千葉県習志野市津田沼2-17-1） \\ 2学生員 千葉工業大学大学院 工学研究科土木工学専攻 (テ275-8588 千葉県習志野市津田沼2-17-1) \\ 3 学生員 千葉工業大学 工学部土木工学科（广275-8588 千葉県習志野市津田沼2-17-1）
}

\begin{abstract}
About 30 years have passed since artificial beaches were built in Japan, and some maintenance problems were appearing in these beaches. This paper reports on the shoreline erosion of an artificial beach "Inage-no-Hama" in Chiba pref.. The artificial beach is constructed in the reclaimed land, and there land subsidence is progressed in present. Beach profile change is analyzed by wave and land subsidence characteristics. As a result, it is found that beach erosion is strongly related to the land subsidence and the erosion rate by subsidence is about 30 percent against by waves.
\end{abstract}

Key Words : beach erosion, shoreline change, reclaimed land, land subsidence

\section{1.はじめに}

各地に人工海浜が建設されるようになってから約 30 年が経過し, 維持管理上の問題が顕在化し始め ている. 最近では, 兵庫県明石市の大蔵海岸におけ る陷没穴への落下死亡事故などの痛ましい事件も発 生し, 建設後の海岸管理の重要性が再認識されてい る.

千葉県に建設されたいなげの浜は日本で最初に建 設された人工海浜であるが，埋立地に建設されたこ ともあって, 維持管理上のさまざまな問題が生じて いる. 図-1 は千葉市の公園緑地による管理費(1998 〜1999)の内訳を示したものであるが，管理費の約 $45 \%$ を侵食対策費が占めており，この侵食対策費を 軽減する必要に迫られている。

本研究は, 侵食対策費を軽減するとともに, 効果 的な人工海浜の維持管理を行う提案をする基礎研究 として, 埋立地に建設された人工海浜「いなげの 浜」の海岸侵食特性について研究を行った.

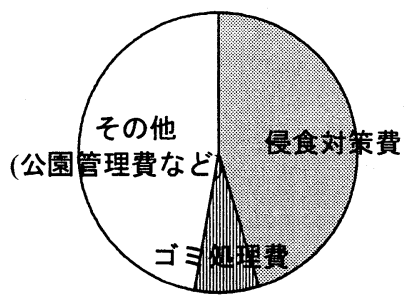

図-1＼cjkstart管理費内訳 (1998年 1999年)

\section{2. いなげの浜の概要}

研究対象域は, 東京湾内奥部に位置する人工海浜 「いなげの浜」である(図-2, 写真-1)。稲毛海浜公 園「いなげの浜」はレクリエーションを目的とした 国内初の人工海浜として計画され，1975年2月から 10月にかけて養浜工事が行われた後, 翌年の1976年 4月に開園した。公園は二つの突堤(長さ $200 \mathrm{~m}$ )に挟 まれた砂浜と背後の公園で構成され, 計画時の海浜 の規模は24ha，沿岸方向の砂浜長が $1200 \mathrm{~m}$, 岸沖方 向の砂浜の幅は満潮時が $50 \mathrm{~m}$, 干潮時が $130 \mathrm{~m}$ である。 しかし, 開園約10年後の1983年から汀線の後退が 目立ち始め, 1996年には, 汀線が竣工時から約 $50 \mathrm{~m}$ 後退した。

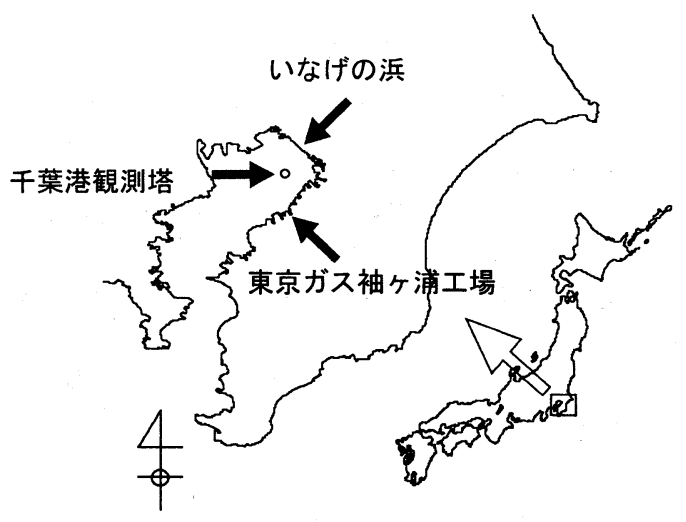

図-2いなげの浜と観測点の位置 


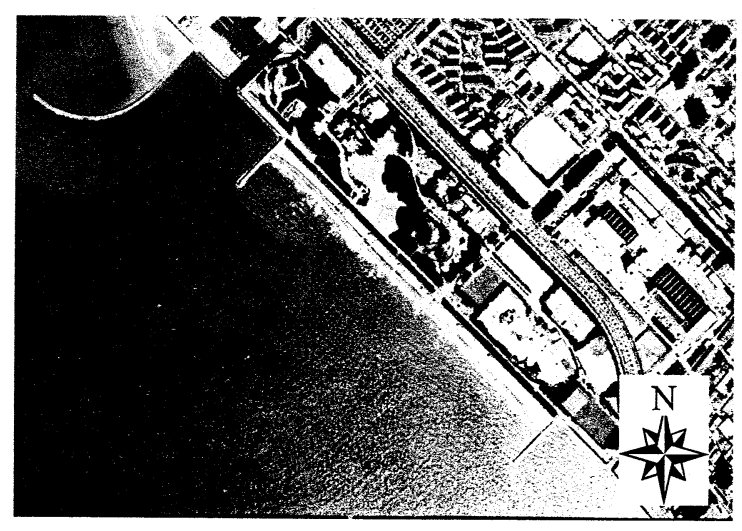

写真-1 いなげの浜 (2002年1月3日)

\section{3. 波浪特性}

\section{（1）解析データ}

解析対象領域の波浪特性を解析するため, 対象地 域に隣接した千葉港観測塔と対象地域の南に位置す る東京ガス袖ケ浦工場の波浪データを用いて, 統計 的特性を解析した。千葉港観測塔では，有義波高・ 周期と風向・風速が，東京ガス袖ケ浦工場では有義 波高・波向および風向・風速が測定されている。本 研究では，千葉港観測塔と東京ガス袖ケ浦工場の データのうち，入手可能であった1998年から2000年 までのデータについて解析した.

\section{(2) 解析結果}

図-3 は有義波高の波高別出現頻度を示したもので ある。千葉港観測塔では $40 \mathrm{~cm}$ 以下の波高が全体の

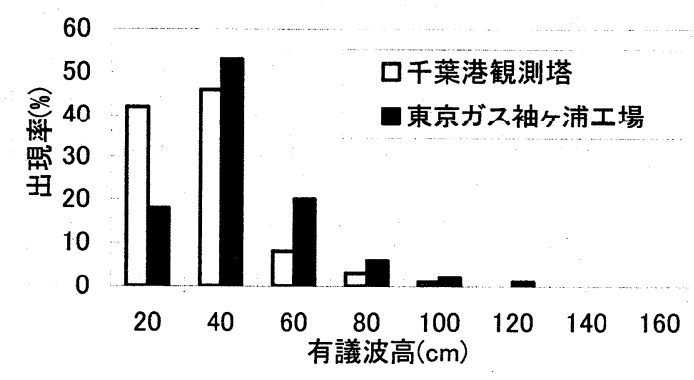

図-3 有義波高別出現率

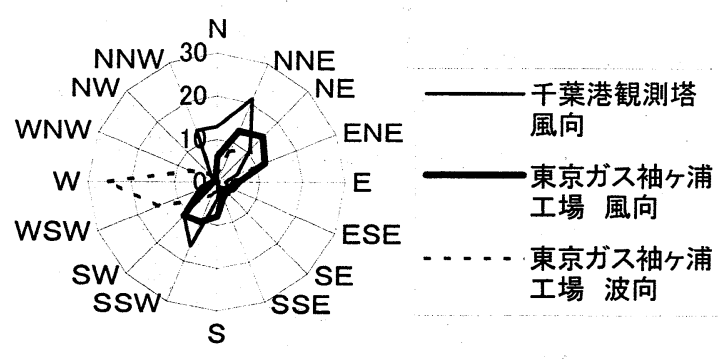

図-4 波向 ·風向別出現率
$90 \%$ 占める。また，東京ガス袖ヶ浦工場でも $40 \mathrm{~cm}$ 以下の波高が全体の $70 \%$ となっている．波向 の出現率(図-4)は西方向(WNW〜WSW)からの波が全 体の約 $50 \%$ と最も多く, 次いで北東方向(NNE〜 ENE)からの波が $30 \%$ であた。 以上のことから， 東京ガス袖ヶ浦工場付近の主な波の入射方向は西で あると言える。しかし，この方向の波は西方向が遮 蔽域となる人工海浜地区ではそのまま適用できない.

当地区での波浪は主に東京湾内に吹き込む風に よって発生すると考えられる。そこで千葉港観測塔 と東京ガス袖ヶ浦工場での風向別出現率をみると， ともに北東方向からの陸風の割合が全体の約 40〜 $50 \%$ ，南西方向からの海風の割合が全体の約 $30 \%$ を占めている．この南西方向からの海風により発生 した波は，いなげの浜にほぼ直角に入射することか ら，近隣の幕張人工海浜における宇多ら ${ }^{2)}$ の解析結 果と同様に，いなげの浜においても岸沖漂砂が卓越 しているものと考えられる。

\section{4. 地形変化特性}

\section{(1) 深浅変化}

はじめに述べたように，いなげの浜では開園後か ら汀線の後退が始まり, 約 8 年後の 1983 年から目 立つようになってきた。図-5 は，計画時から 10 年 ごとの深浅図の変化過程を示したものであるが，年 の経過とともに汀線が後退していく状況がわかる. なお，1983 年に養浜が行われたため，1976 年から 1986 年にかけての変化量は小さい.

1983年頃から顕在化した海岸侵食の対策として, 1984年に養浜工事，さらに1998年から1999年にかけ て養浜・潜堤工事が行われた．工事の直後とその後 数年に対する深浅変化を比較する.

図-6は，養浜前の1984年と14年経過した1998年と の深浅変化を示したものである。

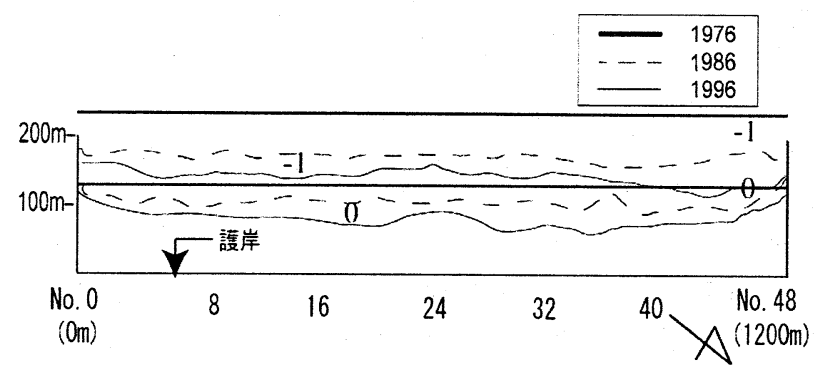

図-5 深浅図の変化過程

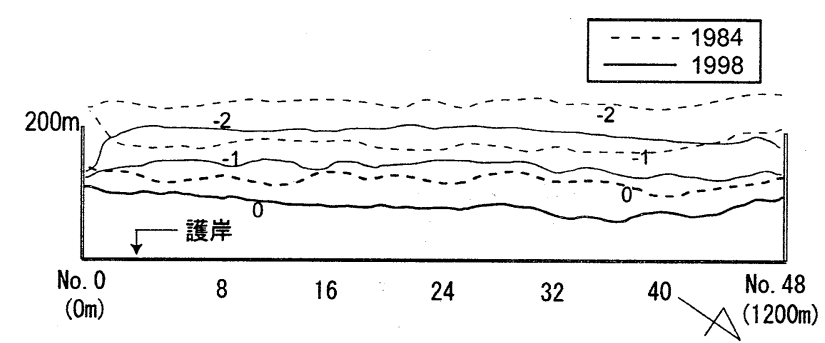

図-6＼cjkstart養浜工事後の深浅変化 (1984年～1998年) 


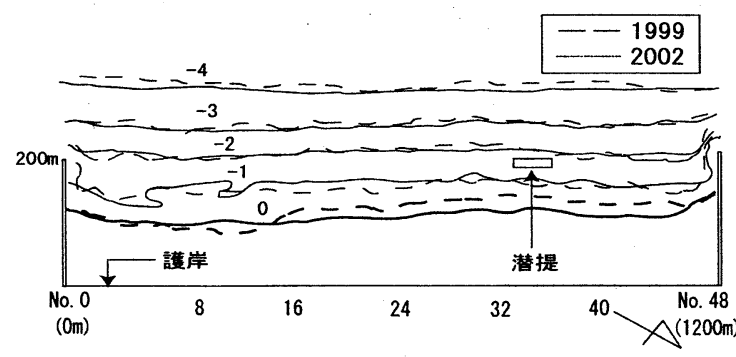

図-7 養浜・潜堤工事後の深浅変化 (1999年 2002年)

1984年と 1998年を比較すると，汀線が平均で約 $30 \mathrm{~m}$ 後退している傾向が認められる。このうちもっとも 侵食されている箇所は測線No.32付近で, 約 $50 \mathrm{~m}$ 汀 線が後退しているのがわかる.

一方，1998年から1999年に行われた養浜・潜堤工 事後とその経過を比較したものが図-7である.

図-7の深浅変化では, 1984年から1998年までの深 浅変化と同様, 測線No.0から 16 まで変化が少なく, 測線No.16から48では大きな侵食傾向が認められる。

\section{（2）汀線変化量}

図-6において汀線変化量が最大となる測点No.30 について, 岸沖方向の海浜変化を比較した. 図-8は, 建設直後の初期勾配と, 養浜工事直前の1998年およ び最近の2002年にかけての海浜勾配の経年変化であ る.

図-8より，建設直後は150mあった汀線が養浜前の 1998年には85mまで後退している. その後, 1998年 から1999年にかけて養浜・潜堤建設工事が行われ，

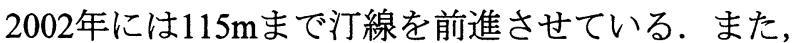
図-8では汀線の移動は見られるものの, 建設当初の $1 / 100$ 勾配は潜堤・養浜工事前後の1998年，2002年ま でほぼ維持されていることが認められる.

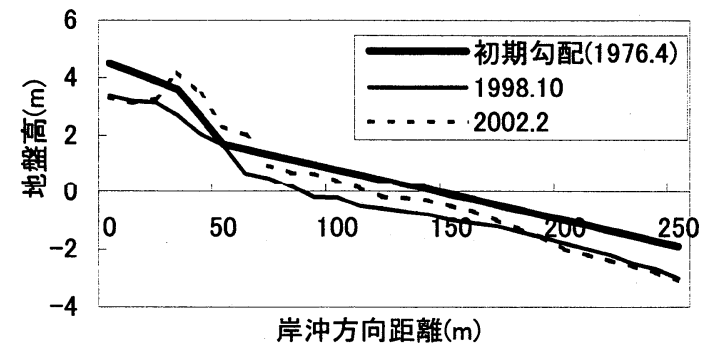

図-8＼cjkstart海浜勾配の経年変化

\section{5. 地盤沈下}

\section{（1）埋立地の沈下}

稲毛海浜公園全体が「軟弱地盤上の埋立地に建設 された公園」という性質上, 建設後に地盤沈下が生 じている．そこで，いなげの浜の後浜背後に位置す る防波護岸(図-9)の沈下量データを用いて沈下特性 について解析を行う。

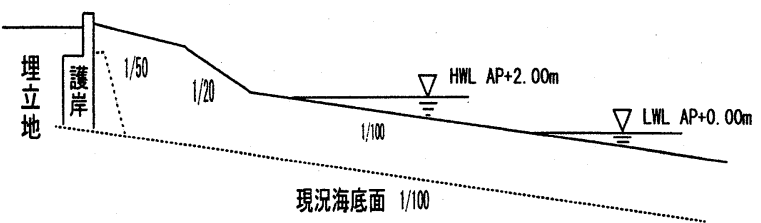

図-9 標準断面図

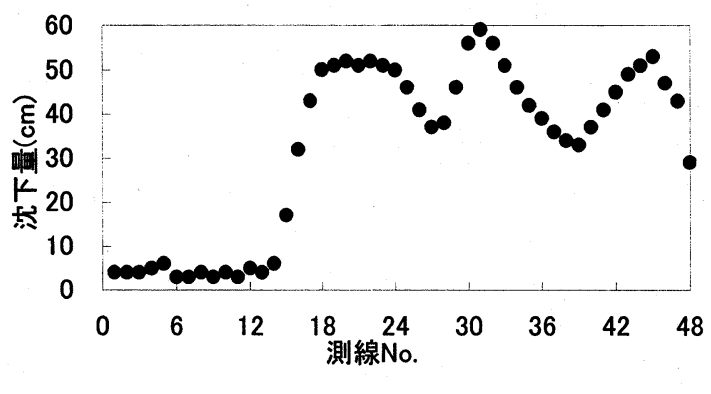

図-10 護岸の沈下量 (1984年〜 1998年)

図-10は, 護岸の1984〜1998年の沈下過程を示した ものである. 測点No.0から12までは比較的沈下が小 さいが，測点No.15から48までは大きな沈下が生じ， 18 年間で最大 $60 \mathrm{~cm}$ 程度の沈下が見られる.

沈下量が最大となる測点No.30および最小の測点 No.6における沈下量の経年変化を示したものが図11である．測点No.30は，沈下の計測を始めた 1984 年から1990年までは沈下速度が大きかったものの， 1995年から2002年にかけては沈下が比較的落ち着い た状態となっていることが認められる.

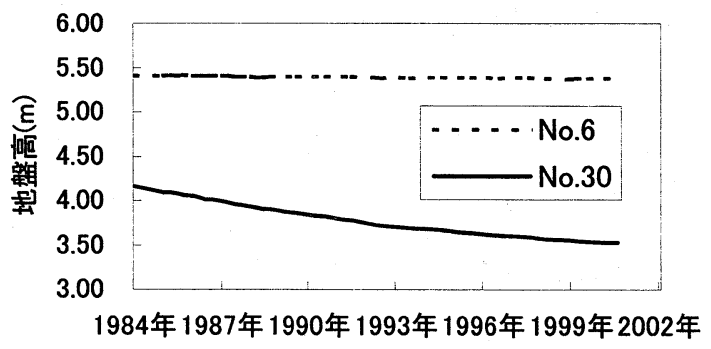

図-11＼cjkstart沈下量の経年変化 (1984年〜2002年)

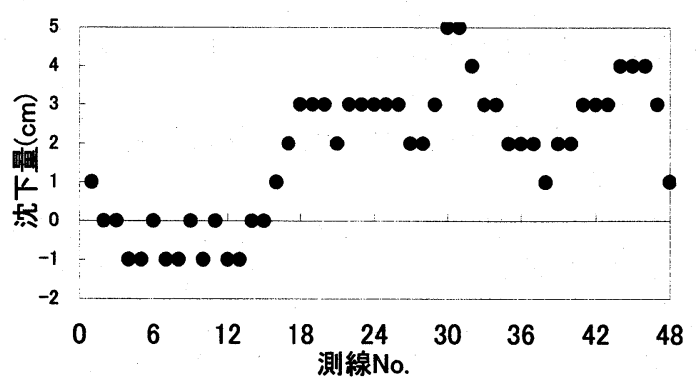

図-12 護岸の沈下量 (1999年〜2002年) 
図-12は，潜提・養浜後の1999年から2002年の護 岸の沈下量を示したものである.14年間の変化を示 した図-10と比較して短い3年間の変化量であるが, 図-6と同様の沈下傾向が認められる. 図-6と10, 図7と12を比較すると, 護岸沈下域と侵食域が一致し ており，地盤沈下はいなげの浜の地形変化に影響を 及ぼしていると考えられる。

\section{（2）汀線変化への影響}

前項までの結果から，いなげの浜の汀線後退には 波浪のほかに地盤沈下が関わっていると考えられる ことから, 汀線変化に対する波浪と地盤沈下の影響 について検討する.

図-8の結果および図-9の標準断面図を見ると，防 波護岸が海浜と同一地盤にあり, 縦断地形の変化が ほぼ一様である，そこで，地盤沈下による汀線変化 量は勾配に各測線での沈下量を乗じることにより求 めることとする.

一方, 波浪による汀線変化量は，3．の波浪特性 解析で使用したデータから岸沖漂砂量を算出し, 汀 線変化量に換算することにより求める. 岸沖漂砂量 の算定式は数多く提案されているが, 本研究では式 (1)の渡辺の算定式を，また，汀線変化量式は式(2) を用いる。

$$
\begin{aligned}
& \phi^{\prime}=7\left(\psi_{m}-\psi_{c}\right) \psi_{m}{ }^{1 / 2} \\
& \frac{\partial x_{s}}{\partial t}+\frac{1}{D_{s}}\left(\frac{\partial Q}{\partial y}-q\right)=0
\end{aligned}
$$

ここに, $\phi^{\prime}$ : 岸沖方向の正味の漂砂量 $(q)$ に関す る無次元漂砂量 $\left(\phi^{\prime}=q / \omega_{0} d\right), \psi_{m}$ : 最大底面せん 断応力に関する Shield数 $\left(\psi_{m}=f_{w} u_{b m}{ }^{2} / 2 s d g\right)$, $\psi_{c}$ : 移動限界に対するShield数, $d$ : 底質粒径, $s$ : 底質の水中比重, $\omega_{0}$ : 底質の沈降速度, $f_{w}$ : Jonssonの摩擦係数, $u_{b m}$ : 底面での波の進行方向の 流速振幅, $g$ : 重力加速度, $t$ : 時間, $D_{s}$ : 漂砂 の移動高, $x_{s}$ : 海岸線の位置, $x$ : 岸方向座標, $y:$ 沿岸方向座標である.

千葉港観測塔で観測された波浪データ(1999.6〜 2000.12)を移動限界水深付近の波浪に換算し，式(1) と式(2)を用いて汀線変化量を求めた。ただし, 波浪 特性結果から本研究では沿岸漂砂は考慮しないこと とした．結果を表-1に示す。

表-1より, 地盤沈下による汀線変化量は- $1.7 \mathrm{~m}$, 波 浪による汀線変化量は-6.7mとなり，その和が深浅 図から読み取った結果とほぼ等しくなった。また， 地盤沈下による変化量は波浪による変化量の約 $30 \%$ となり，無視できない量であることが分かった． 表-1＼cjkstart汀線変化量の計算結果と実測値

\begin{tabular}{|c|c|c|}
\hline 項目 & \multicolumn{2}{|c|}{ 汀線変化量(m) } \\
\hline 地盤沈下 & -1.7 & 合計 \\
\hline 波浪 & -6.7 & -8.4 \\
\hline 深浅図から & \multicolumn{2}{|c|}{-7.6} \\
\hline
\end{tabular}
（1999年6月～2000年12月）

\section{6. 養浜時期の検討}

\section{（1）海浜土砂量}

いなげの浜では1984年と1998〜1999年に養浜が行 われている．そこで，1984年から2002年までの深浅 測量データをもとに，今後の養浜時期について検討 する.

地形変化の解析結果から, いなげの浜での海浜の 変形はほぼ-2m以浅で生じていた。 そこで，-2m以浅 の範囲で海浜土砂量を算出し，その経年変化を示し たものが図-13である.

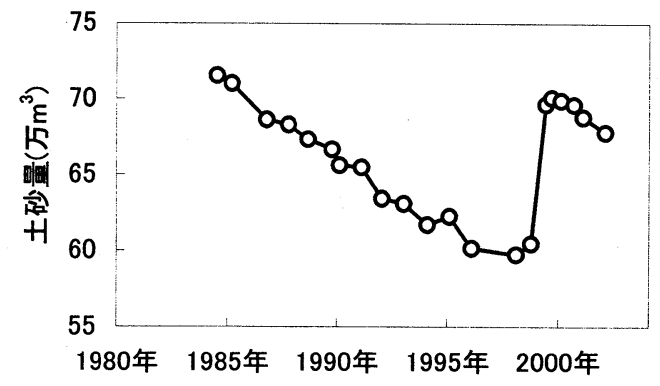

図-13 海浜土砂量の経年変化図

図-13では，養浜工事直後の1984年から養浜工事 前の1998年までの14年間で約 12 万 $\mathrm{m}^{3}$ の土砂量が損失 しているのが分かる.1998年から1999年に行われた 養浜工事により約 10 万 $\mathrm{m}^{3}$ の土砂が補給されたが，養 浜工事後の1999年から2002年には再で減少傾向を示 している.

\section{（2）養浜時期の検討}

潜堤建設前後の海浜土砂量の減少率を比較し, 次 の養浜時期の検討を行う。図-14，15は1984年〜 1998年と 1999年〜2002年までの海浜土砂量の経年変 化とその近似式を示したものである.

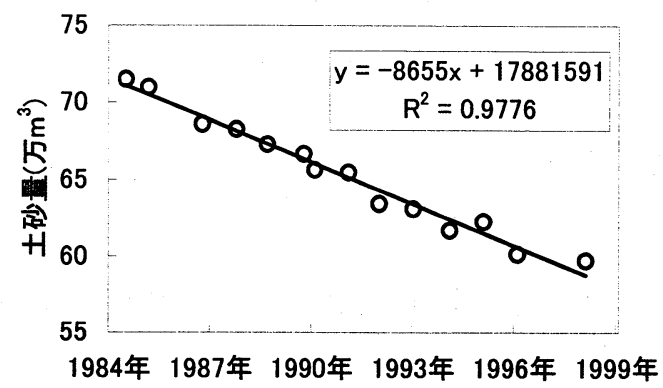

図-14 海浜土砂量の経年変化と近似式 （1984年～1998年） 


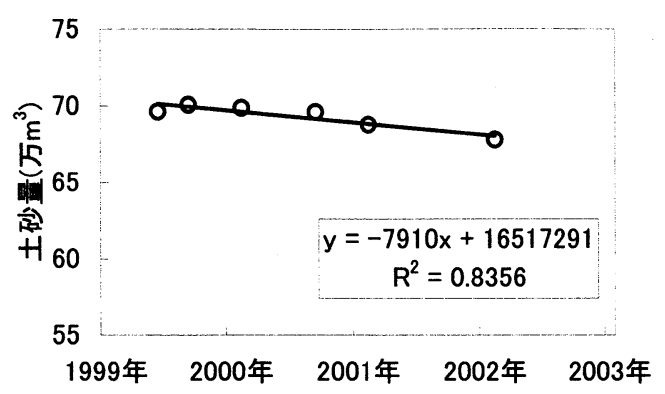

図-15 海浜土砂量の経年変化と近似式 （1999年～2002年）

2つの近似式の勾配を比較すると，潜堤建設後の 1999年から2002年までの海浜土砂減少率の勾配が緩 やかになっており，潜堤の効果があったことが分か る.

図-14より，海浜土砂量が約 60 万 $\mathrm{m}^{3}$ のときに養浜 が行われていることから，養浜時期の目安をこの土 砂量として養浜時期を算出する. 図-16は，潜堤建 設後の近似式と土砂量から海浜土砂量の予測を示し たものである.

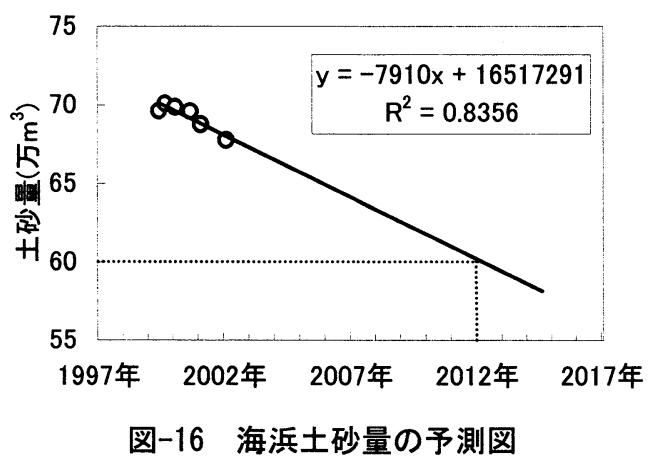

図-16より，2012年頃に海浜土砂量が約 60 万 $\mathrm{m}^{3}$ と なることから, 次の養浜時期は2012年頃になると考 えられる.

\section{7. まとめ}

(1) 気象・海象特性

いなげの浜では, 有義波高は主に $40 \mathrm{~cm}$ 以下の波 が全体の $70 \%$ 占め, 風向は北東, 南西方向からの
風が卓越していた．この南西方向からの海風により 発生した波は，いなげの浜にほぼ直角に入射するこ とから，岸沖漂砂が卓越しているものと考えられた。 (2) 地形変化特性

1984年から 1999年までに汀線が平均で30m後退し， もっとも侵食されている箇所で約 $50 \mathrm{~m}$ 汀線が後退し ていた.1999年から2002年までの深浅変化も1984年 から1998年までと同様な侵食傾向が認められた.

(3) 地盤沈下

地盤沈下は小さい領域と大きい領域に明膫に分か れ，18年間で最大 $60 \mathrm{~cm}$ 程度の沈下が見られた。また, 護岸沈下域と侵食域が一致しており，地盤沈下はい なげの浜の地形変化に影響を及ぼしていると考えら れた。

(4) 汀線変化量

1999年6月から2000年12月までの波浪特性の解析 結果から, 地盤沈下による汀線変化量は- $1.7 \mathrm{~m}$, 波 による汀線変化量は-6.7m となり，その和が深浅図 から読み取った結果とほぼ等しくなった．また，地 盤沈下による侵食量は波浪によるものの約 $30 \%$ とな り，無視できない量であることが分かった.

(5) 養浜時期の検討

1998年から1999年にかけて行われた潜提・養浜工 事後で海浜土砂量の減少率が緩やかになった. 2012 年頃に海浜土砂量が約 60 万 $\mathrm{m}^{3}$ となることから，次の 養浜時期は2012年頃になると考えられることが分 かった.

謝辞 : 本研究を進めるに際し，千葉市花見川・美浜 公園緑地事務所には資料提供の便宜を図っていただ いた. また, 千葉工業大学付属研究所助成金の援助 を受けた．記して謝意を表する。

\section{参考文献}

1) 米田規幸・矢内栄二 : 京葉地区の漂砂特性につい $\tau$, 第29回関東支部技術研究発表会講演概要集, pp250-251, 2002.

2) 宇多高明・堀越信雄・林順一:入り組んだ湾奥部 での人工海浜計画上の留意点一東京湾を例として 一, 海岸工学論文集, 第41巻, pp591-595, 1994.

3) 宇多高明(著) : 日本の海岸侵食, 442p., 1997.

4) 服部昌太郎(著) : 海岸工学, 230p., 1987. 